\title{
FAIR LABOR STANDARDS UNDER THE PORTAL TO PORTAL ACT
}

The Portal to Portal Act of $x 947^{\mathrm{I}}$ was passed ostensibly as emergency legislation to relieve employers from existing liabilities which accrued as a result of the decision of the Supreme Court in Anderson v. Mt. Clemens Pottery Co. ${ }^{2}$ Despite assurance to the contrary, however, the Act goes beyond the mere granting of relief from existing liabilities of this sort. It stands as the first major revision of the federal wages and hour program initiated in 1938 with the passage of the Fair Labor Standards Act, ${ }^{3}$ and to a large extent it limits, modifies, and abolishes many rights of those workers covered by that Act. The extent of these changes has aroused as much controversy as its constitutionality. ${ }^{4}$

The Fair Labor Standards Act provides that no employee engaged in commerce or in the production of goods for commerce shall be paid less than forty cents per hour for his work and that such employees shall be paid at a rate of one and one-half times the regular rate for all hours worked in excess of forty per week. ${ }^{s}$ The statute was designed to eliminate in interstate commerce conditions which were considered detrimental to the maintenance of the minimum standards of living necessary for health, efficiency, and general well-being of workers. ${ }^{6}$ The Supreme Court recognized that, enacted as it was to protect the "rights of those who toil, who sacrifice a full measure of freedom and talents to the use and profits of others," " the Fair Labor Standards Act is a remedial and humanitarian measure and must not be interpreted in a narrow or grudging manner. ${ }^{8}$ The courts have taken advantage of the lack of precise statutory definition of many of the terms in which the Fair Labor Standards Act is written. In applying these general terms to specific fact situations, they have recognized the broad economic policy of eliminating sub-standard labor conditions and spreading employment by placing financial pressure on the employer through the overtime pay requirement. 9 This inclination on the part of the courts is prompted, in

×H.R. 2157, 8oth Cong. Ist Sess. (Pub. L. No. 49, May 14, 1947).

2328 U.S. 680 (1946).

${ }^{3} 5^{2}$ Stat. I060 (1938), 29 U.S.C.A. $\$ \S 201-19$ (1938). For a symposium on the legislative history, administration, and coverage of the Act see 6 Law \& Contemp. Prob. 32I-490 (1939).

4 The constitutionality of various provisions of the Portal Act has been sustained by the federal district courts which have considered the question: see Cochran v. St. Paul \& Tacoma Lumber Co., 73 F. Supp. 288 (Wash., 1947); Lasater v. Hercules Powder Co., 73 F. Supp. 265 (Tenn., I947); Boehle v. Electro-Metallurgical Co., 72 F. Supp. 2I (Ore., I947); Burfeind v. Eagle-Picher Co. of Texas, 7 I F. Supp. 929 (Tex., I947); Constitutionality of the Portal-toPortal Act, 47 Col. L. Rev. IoIo (1947).

${ }_{5} 52$ Stat. 1063 (1938), 29 U.S.C.A. $\$ \$ 206,207$ (194I).

${ }^{6} 52$ Stat. 1060 (1938), 29 U.S.C.A. \& 202 (1938).

7 Tennessee Coal, Iron, \& R. Co. v. Muscoda Local No. I23, 32I U.S. 590, 597 (I944).

${ }^{8}$ Ibid.

9 Overnight Trans. Co. v. Missel, 316 U.S. 572, 578 (1942); Walling v. Helmerich \& Payne, 323 U.S. 37, 4r (1944); Walling v. Youngerman-Reynolds Hardware Co., 325 U.S. 4I9, 423 (I945); Jewell Ridge Coal Corp. v. Local No. 6r67, United Mine Workers of America, 325 U.S. I6I, I67 (I945). 
part, by Congressional debates ${ }^{10}$ which indicate that the primary purpose of the Fair Labor Standards Act ". . . . was to aid the unprotected, unorganized and lowest paid of the nation's working population; that is, those employees who lack sufficient bargaining power to secure for themselves a minimum subsistence wage. ${ }^{\prime I I}$ Consequently, the Act has been given a liberal interpretation, ${ }^{12}$ and the exemptions therefrom have been narrowly construed and limited to those who can meet the burden of showing that they come "plainly and unmistakably within [the] terms and spirit" ${ }^{\prime 3}$ of such an exemption.

When Congress enacted the Portal to Portal Act in May 1947, it declared in its statement of findings and policy that

the Fair Labor Standards Act has been interpreted judicially in disregard of long established customs, practices and contracts between employers and employees, thereby creating wholly unexpected liabilities, immense in amount and retroactive in operation, upon employers. ......4

which have resulted in a burden and obstruction to interstate commerce. This statement of policy was apparently intended as a direct censure of the Supreme Court's decision in the Mt. Clemens case, in which it was held that all employee activity falling within its definition of work ${ }^{\mathrm{rs}}$ " .... must be included in the statutory workweek and compensated accordingly, regardless of contrary custom or contract."16 However, if this announced Congressional policy should be taken by the courts as a repudiation of the liberal approach they have taken in interpreting the Fair Labor Standards Act, it will result in a drastic impairment of the federal wage and hour program. Such a result was foreseen by the President when he signed the Act ${ }^{\mathrm{xz}}$ and by the Administrator of the Wage and Hour

so 8x Cong. Rec. 7652, 7672, 7885 (1937); 82 Cong. Rec. 1386, r395, x49r, I505 (1937); 83 Cong. Rec. $7283,7298,9260,9265$ (1938). See also H. Rep. No. $1452,75^{\text {th }}$ Cong. rst Sess. at 9 (1938); S. Rep. No. 884, 75th Cong. rst Sess. pp. 3-4 (1938).

Ix Brooklyn Savings Bank v. O'Neil, 324 U.S. 697, 707 (1945).

${ }^{22}$ See Roland Electrical Co. v. Walling, 326 U.S. 657 (I946); Brooklyn Savings Bank v. O'Neil, 324 U.S. 697 (1945); Walling v. Rosenwasser, 323 U.S. 360 (I945).

${ }^{13}$ A. H. Phillips v. Walling, 324 U.S. 490, 493 (r945); see Walling v. General Industries Co., 67 S.Ct. $88_{3}$ (1947).

¿ Pub. I. No. 49, 8oth Cong. Ist Sess. \& I (a) (May I4, 1947).

ts For the purposes of the Fair Labor Standards Act, work or employment had been defined as meaning "physical or mental exertion (whether burdensome or not), controlled or required by the employer, and pursued necessarily and primarily for the benefit of the employer and his business," Tennessee Coal, Iron \& R. Co. v. Muscoda Local No. I23, 32I U.S. 590, 598 (1944); cf. Jewell Ridge Coal Corp. v. Local No. 6r67 United Mine Workers of America, 325 U.S. $16 \mathrm{Y}$ (1945), including all time spent in active or inactive duties which an employee is engaged to perform except time spent in eating and sleeping. Armour \& Co. v. Wantock, 323 U.S. I26, I32 (I944); Skidmore v. Swift \& Co., 323 U.S. I34, 136 (I944).

${ }^{16}$ Anderson v. Mt. Clemens Pottery Co., 328 U.S. 680, 692 (1946).

${ }^{27}$ In signing the Portal Act the President declared: "I am confident that the purpose of the main provisions of the Act is to eliminate the immense potential liabilities which have arisen as the result of the portal to portal claims. It is not the purpose of the Act to permit violation of our fundamental wage and hour standards, or to allow a lowering of these standards." H.R. Doc. No. 247, 8oth Cong. Ist Sess. (1947). 
Division of the Department of Labor. ${ }^{\mathrm{I}}$ Both the President and the Administrator emphasized, however, that the Portal Act should not be interpreted as changing ".... the national policy declared in Section 2 of the Fair Labor Standards Act of eliminating labor conditions detrimental to the maintenance of the minimum standards of living necessary for health, efficiency, and general well-being of workers." 19

Section 2 of the Portal Act defines the concept of "hours worked" for which minimum wages and overtime compensation must be paid with respect to existing claims accruing on or before May $\mathrm{x}_{4}$, I947. Section 4 does the same with respect to all causes of action arising after May I4, 1947. The Act gives "relief" to employers from all existing "portal-to-portal" claims by providing that no court of the United States or of any state shall have jurisdiction of any action for compensation or for injunctive relief under the Fair Labor Standards Act unless the activity in question was compensable by an express provision of a written or unwritten contract, or a custom or practice in effect at the specific place of work, during the time in which it was performed, and in regard to the specific activity involved. ${ }^{20}$ This provision not only bars all the strictly "portalto-portal" claims not covered by a previous contract or custom, but also bars claims for compensation for any and all activities performed within the entire 24-hour day, unless made compensable by contract or custom. ${ }^{2 x}$ The statute requires a strict interpretation of contract and custom. The contract in question must be an "express contract,",22 and the activity in question must be engaged in during the portion of the day with respect to which it was made compensable. ${ }^{23}$ This would seem to preclude an interpretation that a particular activity such as walking time was compensable by "necessary implication" from the terms of an effective contract, or that a past activity is compensable merely because it had previously been so held by judicial or administrative interpretation. The same strict interpretation is required in regard to activities made compensable by custom or practice, with the additional requirement that the custom or practice must cover the specific activity at the place of employment, as distinguished from an industry or area practice. ${ }^{24}$ Thus, past activities such as neces-

${ }^{18}$ Wage and Hour Division, Interpretation of Portal-to-Portal Act, 21 Lab. Rel. Rep. (Wages and Hours) $306 \mathrm{r}, 300_{3}$ (1947).

I9 Ibid., at 3063 .

${ }^{20}$ Pub. L. No. 49, 8oth Cong. Ist Sess. § 2 (May I4, x947).

${ }^{2 x}$ See statements of Senator Donnell, 93 Cong. Rec. 2196, 2255, 2440 (March I7, I8, and 2I, 1947).

$2=$ Pub. L. No. 49, 8oth Cong. Ist Sess., $\$ 2(a)($ I) (May I4, I947).

${ }_{23}$ Pub. L. No. 49, 80th Cong. Ist Sess., $\S 2$ (b) (May I4, I947).

${ }^{4}$ Pub. L. No. 49, 8oth Cong. Ist Sess., § 2(a)(2) (May I4, I947). 
sary repairs to machinery, ${ }^{25}$ distribution of work materials, ${ }^{26}$ and waiting time required by the employer, ${ }^{27}$ which were never considered to fall within the "portal" category and which were not in issue in the $M t$. Clemens case, are not compensable unless specifically covered in the contract of employment or made compensable by an applicable custom. This achieves the anomalous result that an employee who performed activities of this type with knowledge that his compensation was to be governed by the definition of "hours worked" as defined by the Administrator of the Wage and Hour Division, ${ }^{28}$ and in reliance on the judicial interpretation of the highest court in the land, is denied any compensation for this work. This result is reached despite the fact that compensation for like activity was enforced by the courts prior to the passage of the Portal Act, ${ }^{29}$ and these activities now constitute "hours worked" if performed after May I4, 1947, under the standards set up in Section 4 of the Act in respect to future claims. ${ }^{30}$ This anomaly exists because Congress deemed it impossible to examine all the cases then pending and to separate the "just" claims from the "unjust" claims. ${ }^{3 \mathrm{x}}$

25 In connection with the operation of a lathe an employee will frequently, at the commencement of his workday, oil, grease, or clean his machine, or install a new cutting tool. The Administrator of the Wage and Hour Division has always regarded such an activity as work and as compensable under the Fair Labor Standards Act. See Wage and Hour Division, Interpretative Bulletin No. I3, issued May, I939, revised November, I940, 2 C.C.H. Lab. Law Serv. $\pi_{32, I_{3}}$ (1940).

${ }^{26}$ In the case of a garment worker who is required to report earlier than the other employees and who during such time distributes clothing at the work benches of other employees and gets machinery in readiness for operation by other employees, no compensation will be allowed under Section 2 of the Portal Act in the absence of a contract or custom to pay for such activities. Compensation for a like activity performed prior to the passage of the Act was enforced by the Wage and Hour Division. See Wage and Hour Division, Interpretative Bulletin No. 13, op. cit. supra note 25.

${ }^{27}$ In 1944 the Supreme Court held that compensation under the Fair Labor Standards Act must be paid for all time which an employee spent waiting on the employers' premises, except for the hours spent sleeping or eating. Armour \& Co. v. Wantock, 323 U.S. I 26 (I944); Skidmore v. Swift \& Co., 323 U.S. I34 (I944); cf. Walling v. Allied Messenger Service, Inc., 47 F. Supp. 773 (N.Y., I942); Travis v. Ray, 4I F. Supp. 6 (Ky., I94I).

${ }^{28}$ Wage and Hour Division Interpretative Bulletin No. 13, op. cit. supra note 25.

${ }^{29}$ Walling v. Frank, 62 F. Supp. 261 (Ky., I945) (compensation granted for daily time spent cleaning and oiling machines); Ballard v. Consolidated Steel Corp., 6r F. Supp. 996 (Cal., 1945) (time spent obtaining necessary work equipment held compensable); Philpott v. Standard Oil Co., 53 F. Supp. 833 (Ohio, 1943) (time spent by employees of oil company in preliminary activities as directed by employer held compensable).

${ }^{30}$ Examples of what activities are deemed to constitute an integral part of the principal activity and will be compensable under Section 4 of the Portal Act may be found in Report of the Senate Committee on the Judiciary on S. 70, 8oth Cong. Ist Sess., at 48 (1947); see Wage and Hour Divisions, Interpretation of the Portal-to-Portal Act, 2I Lab. Rel. Rep. (Wages and Hours) $306 \mathrm{r}, 3070$ (I947).

${ }_{31}$ "The mere fact that we shall doubtless wipe out some rights here and there-we hope they will not be many, but some of them here and there-in the course of remedying this problem. . . . "93 Cong. Rec. 220I (March I7, 1947). 
As in the case of accrued claims covered by Section 2, a general rule is also stated in Section 4 with respect to what constitutes "hours worked" for all causes of action arising in the future. This section does not cover situations within the entire 24-hour period as did Section 2, but merely the time from "whistle to whistle." $3^{2}$ It provides specifically that no employer shall be subject to any liability for or on account of the following activities of an employee engaged in after May 14, 1947:

(I) walking, riding, or traveling to and from the actual place of performance of the principal activity or activities which such employee is engaged to perform, and

(2) activities which are preliminary to or postliminary to said principal activity activities

which occur either prior to the time on any particular workday at which such employee commences, or subsequent to the time on any parrticular workday at which he ceases, such principal activity or activities. ${ }^{33}$

The activities listed above will be compensable if covered by the express terms of a written or unwritten contract in effect at the time of performance, or by custom or practice in effect at the place of employment and not inconsistent with an effective contract. ${ }^{34}$ It can be seen that this is an attempt to "outlaw" in the future all claims for compensation based on that "twilight zone" of activity over which the "portal-to-portal" issue arose, unless they are specifically covered by contract, custom, or practice. Although this provision in regard to future claims is not so drastic a curtailment of the rights of workers as that in respect to existing claims, it nevertheless works to the disadvantage of the unorganized workers, the very group for whose benefit the wage and hour program was originally enacted. This provision will fall most heavily upon the nine million unorganized workers covered by the Fair Labor Standards Act, ${ }^{35}$ who do not have the bargaining power necessary to secure from their employers an agreement that compensation will be paid for other than the "principal activity." This differential between these workers and those covered by the collective bargaining agreements of powerful unions may well act as a boon to the organization of strong unions among the presently non-unionized employees covered by the Fair Labor Standards Act.

In addition to the relief which has been granted employers by redefining and limiting the concept of "hours worked," the Portal Act has remedied another complaint of various employer groups. It has been the contention of many employers that the Fair Labor Standards Act failed to protect those employers who acted in good faith against the financial liability which could be imposed upon them by the shifting and conflicting administrative and judicial interpre-

${ }^{32}$ See statement of Senator Donnell, 93 Cong. Rec. 2255 (March I8, I947).

33 Pub. L. No. 49, 8oth Cong. Ist Sess., § 4(a) (May I4, I947).

${ }_{34}$ Pub. L. No. 49, 8oth Cong. Ist Sess., \& 4(b) (May I4, I947).

35 Administrator of the Wage and Hour Division and Public Contracts Division of the Department of Labor, Annual Report to 8oth Cong. Ist Sess. (Jan. 2, I947). 
tations of the statute. ${ }^{36}$ To meet this situation the Portal Act provides that in regard to all claims which accrued before the passage of the Act, no employer shall be subject to:

.... any liability or punishment [under the Act] for or on account of the failure of the employer to pay minimum wages or overtime compensation.... if he pleads and proves that the act or omission complained of was in good faith in conformity with and in reliance on any administrative regulation, order, ruling, approval or interpretation of any agency of the United States, or any administrative practice or enforcement policy of such agency with respect to the class of employers to which he belonged. 37

This provision allows an employer relief from any past liability under the Fair Labor Standards Act if he relied in good faith on any written or unwritten statement of any federal agency, even though such an opinion may have been in conflict with the interpretation of the Administrator of the Wage and Hour Division or the Supreme Court of the United States. On the other hand, a worker who engaged in certain employment with actual knowledge that the Wage and Hour Administrator and the Supreme Court had held that it was covered by the Fair Labor Standards Act, is denied the protection of the minimum wage and overtime guaranties if his employer erroneously relied on the interpretation of another federal agency. An examination of the wage and hour cases decided during recent years reveals that much confusion has been present in rulings of the various agencies and the courts on the coverage of the Act, especially as to who is covered by the various exemptions, and what constitutes a regular hourly wage. ${ }^{8}$ In most instances an employer will not find it difficult to prove reliance on the ruling of some federal agency. 39 A similar "good faith" defense has been provided against all causes of action arising after May I4, I947, with two important differences: the administrative ruling relied upon must be in writing, and it must be a ruling of the Wage and Hour Administrator..$^{\circ}$ By providing a defense for employers in all actions in which they can show that their acts or omissions were based on a written regulation, order, or ruling of the Wage and

${ }^{36}$ For a summary of the complaints and recommendations of various interested groups in connection with the Fair Labor Standards Act see Hearings before a Subcommittee of the Committee on the Judiciary on S. 70, 8oth Cong. Ist Sess. (I947); Hearings before Subcommittee No. 2 of the Committee of the Judiciary on H.R. 584, 8oth Cong. Ist Sess. (r947).

37 Pub. L. No. 49, 8oth Cong. Ist Sess., $\$ 9$ (May 14, I947).

${ }^{38}$ An excellent discussion of the cases arising under the Fair Labor Standards Act and an illustration of the confusion present can be found in: Levy, Belo Revisited, I5 Geo. Wash. L. Rev. 39 (I946); Dodd, The Supreme Court and the Fair Labor Standards Act, 194I-1945, 59 Harv. L. Rev. 32I (I946); Feldman, Algebra and the Supreme Court, 40 Ill. L. Rev. 489 (1946); Davisson, Coverage of the Fair Labor Standards Act, 43 Mich. L. Rev. 867 (1945).

39 During recent years the following federal agencies have issued interpretations which affect wage and hour questions: Public Contracts Administration, Maritime Commission, War Shipping Administration, Salary Stabilization Unit of the Treasury Department, War Labor Board, and the Interstate Commerce Commission.

40 Pub. L. No. 49, 8oth Cong. Ist Sess., \& Io (May 14, I947). 
Hour Administrator, the Act has made these interpretations of the Administrator binding on employees but not on employers. Although the employer is always protected by reliance on the Administrator's interpretation, there is no provision in the Act whereby an employee may in the future perform certain activities with the assurance that he will be compensated in accordance with the written opinion of the Administrator, since the courts may still reach an opposite conclusion..$^{4}$

The Fair Labor Standards Act gave to every employee who failed to receive the minimum wages and overtime compensation required by the Act a cause of action against his employer for the amount by which he was underpaid, ${ }^{42}$ plus an equal additional amount as liquidated damages. An action to recover such liability could be maintained by:

.... any one or more employees for and in behalf of himself or themselves and other employees similarly situated, or such employee or employees may designate an agent or representative to maintain such action for and in behalf of all employees similarly situated. 43

The courts have held that this provision is not penal in its nature 44 but rather that such damages constitute compensation for the hardships caused by the employers' retention of a workman's pay where the required wages are not paid on time. 45 Until the passage of the Portal Act no claim of an employee for minimum wages or overtime compensation under this provision could be defeated by a settlement or compromise for less than double the alleged underpayments, $4^{6}$ even in the face of a bona fide dispute as to coverage under the Act.47

In the case of a valid claim for wages, which accrued prior to May 14, I947, the Portal Act has nullified these decisions, in part. It provides that any accrued claim and any action instituted to enforce such a claim may be compromised, adjusted, settled, or released if there exists a bona fide dispute as to wages payable and if the settlement provides for the payment of at least the statutory minimum (4o\& per hour) and time and a half for overtime. ${ }^{4} \mathrm{It}$ also authorizes an employee "hereafter" to waive his right to liquidated damages, in whole or in

4 Although the courts have attached great weight to the interpretations of the Administrator, Skidmore v. Swift \& Co., 323 U.S. 134, 140 (1944); Overnight Motor Trans. Co. v. Missel, 316 U.S. 572 (1942), the Supreme Court has in several instances come out with decisions contrary to administrative interpretation. Walling v. Halliburton Oil Well Cementing Co., 67 S.Ct. 1056 (1947); Walling v. Belo Corp., 316 U.S. 624 (1942).

${ }_{42} 52$ Stat. 1069 (I938), 29 U.S.C.A. $\$ 216$ (b) (I940). The procedural aspects of employees' suits under the Act are extensively treated in Gerber and Galfand, Employee Suits under the Fair Labor Standards Act, 95 U. of Pa. L. Rev. 505 (I947).

${ }^{43} 5^{2}$ Stat. 1069 (1938), 29 U.S.C.A: $\$ 216($ b) (I940).

44 Overnight Motor Trans. Co. v. Missel, 3 I6 U.S. 572, 583 (I942).

15 Brooklyn Savings Bank v. O'Neil, 324 U.S. 697, 707 (1945).

${ }_{4}^{6} \mathrm{Ibid}$. , at $707-8$.

47 D. A. Schulte, Inc. v. Gangi, 328 U.S. 108 (Ig46).

${ }^{8}$ Pub. L. No. 49 , 8oth Cong. Ist Sess., \&3(a) (May 14, 1947). 
part, as to claims which accrued before the Portal Act became effective..$^{49}$ The condition that a settlement may not be entered into unless a bona fide dispute exists as to wages payable may be met in nearly every case where a claim for additional compensation is made..$^{50}$ The sponsors of the Portal Act in Congress recognized that a provision such as this might well result in ". . . . the utter demolition of the Fair Labor Standards Act"sx because of the pressure which might be brought on employees to settle their otherwise valid claims. Consequently, Congress inserted this provision with respect to existing causes of action only. Thus, with respect to these provisions also, the Portal Act has failed to protect the unorganized worker who may not have the economic power necessary to enable him to resist such a settlement.

Another basic change in the underlying philosophy of the Fair Labor Standards Act may be found in the Portal Act's treatment of liquidated damages in respect to future causes of action. The courts recognized in Section $I 6(b)$ of the Fair Labor Standards Act (the provision for liquidated damages) a Congressional intention to guard against the possibility that an employer who gambles on evading the Act may, if detected, perform his statutory duty simply by paying the wages due. The Supreme Court realized that "knowledge on the part of the employer that he can not escape liability for liquidated damages .... tends to insure compliance in the first place," ${ }_{52}$ and that the failure to pay the statutory minimum or overtime compensation may be so detrimental to the minimum standards of living necessary, that ".... double payment must be made in the event of delay in order to insure restoration of the worker to that minimum standard of well-being." 53 Consequently, the court recognized that the provision for liquidated damages is not discretionary, but mandatory. ${ }^{54}$ However, Section II of the Portal Act authorizes the courts, at their discretion, in suits brought under Section I6(b) of the Fair Labor Standards Act, to award no liquidated damages or to award any amount thereof not to exceed the amount specified in Section I6(b), if ". . . . the employer shows to the satisfaction of the

49 Pub. L. No. 49, 8oth Cong. Ist Sess., §3(b) (May I4, I947).

$5^{\circ}$ Representative Walter, explaining the conference agreement to the House of Representatives, indicated that the phrase "dispute as to the amount payable" would include disagreements as to matters of law such as whether an employee's work is covered by the Fair Labor Standards Act or whether the employee is exempt, as well as disagreements as to matters of fact such as the number of hours worked or the wage rates paid. 93 Cong. Rec. 45I5 (May I, I947); see Wage and Hour Division, Interpretation of the Portal-to-Portal Act, 2I Lab. Rel. Rep. (Wages and Hours) 306r, 3088 (1947).

${ }^{5 x}$ Senator Donnell (Chairman of the Senate Subcommittee which drafted the Portal to Portal Act) stated: "At this point let me say that we have recognized in our bill, by not making the provision for compromise and settlement applicable to the future, that there is a grave danger of placing a provision of that kind in the bill as to future activities, because such a provision might well result, as in the case of the Brooklyn Savings Bank, in the utter demolition of the Fair Labor Practices [Standards] Act." 93 Cong. Rec. 2192 (March 17, 1947).

52 Brooklyn Savings Bank v. O'Neil, 324 U.S. 697, 7ro (1945).

53 Tbid., at 707 .

4 Overnight Motor Trans. Co. v. Missel, 316 U.S. 572, 582 (1942). 
court that the act or omission [giving rise to the employee's suit] was in good faith and that he had reasonable grounds for believing that his act or omission was not a violation of . . . ." ${ }_{55}$ the Fair Labor Standards Act. By adopting this provision, Congress has stripped Section I6(b) of its deterrent effects to a considerable extent.

By an express amendment of Section 16(b) of the Fair Labor Standards Act, the Portal Act no longer permits an employee or employees to designate an agent or representative (other than a member of the affected group) to maintain an action for and in behalf of all employees similarly situated. ${ }^{66}$ Collective actions brought by an employee or employees (a real party in interest) may still be maintained but ". . . no employee shall be a party plaintiff to any such action unless he gives his consent in writing to become such a party and such consent is filed in the court in which such action is brought." ${ }^{77}$ This amendment is applicable only to actions which are commenced on or after the date of the enactment of the Portal Act..$^{8}$ The banning of representative actions for unpaid wages is an obvious device to prevent the maintenance of employee suits by labor unions. ${ }^{59}$ Moreover, even though there is no prohibition of collective actions, the requirement that all parties plaintiff in such an action must file their written consent in the court, is a serious hindrance to employee suits. During periods of rapid labor turnover an employee frequently leaves the service of an employer before he becomes aware that he had not been paid the amount of ' wages due him under the statute. Prior to the passage of the Portal Act, such an employee when one of a class that had maintained a successful action in a class suit could come into court later and take advantage of the judgment..$^{60}$

The Portal Act contains a further procedural restriction on the rights of employees by writing a relatively short statute of limitations into the Fair Labor Standards Act. That Act, as it was originally passed in 1938 , contained no statute of limitations in regard to the actions brought under it, and state statutes of limitations varying from one to eight years were in effect..$^{6 \mathrm{~T}}$ The varying state

${ }_{55}$ Pub. L. No. 49, 8oth Cong. Ist Sess., § Ix (May I4, 1947).

${ }_{56}$ "The second sentence of section $\mathrm{r} 6(\mathrm{~b}$.) of the Fair Labor Standards Act of I938, as amended, is amended to read as follows: 'Action to recover such liability may be maintained in any court of competent jurisdiction by any one or more employees for and in behalf of himself or themselves and other employees similarly situated." "Pub. L. No. 49, 8oth Cong. Ist Sess., § (a) (May I4, I947).

57 Pub. L. No. 49, 8oth Cong. Ist Sess., $\$ 5$ (a) (May I4, r947).

${ }^{8}$ Pub. L. No. 49 , 8oth Cong. Ist Sess., $\S 5$ (b) (May I4, I947).

59 Both the Tennessee and Jewell Ridge cases were representative union actions as were hundreds of the "portal" claims filed after the Mt. Clemens decision. For a detailed list of suits that have been filed see Hearings before Subcommittee No. 2 of the Committee of the Judiciary on H.R. 584, 8oth Cong. Ist Sess. 387-95 (1947).

${ }^{60}$ See Pentland v. Dravo Corp., I52 F. 2d 85I (C.C.A. 3d, 1945).

${ }^{61}$ A summary of the state statutes of limitations applicable to suits under Section I6(b) on the Fair Labor Standards Act is presented at page $5 \circ$ of the Report of the Senate Committee on the Judiciary on S. 70, 8oth Cong. Ist Sess. (1947). A six-month statute of limita- 
statutes gave an advantage to violators of the Act in states which had restrictive statutes of limitations and barred many suits of workers for wages legally due. The Portal Act attempts elimination of this discrimination. However, instead of following the recommendation of the Wage and Hour Administrator and enacting a three-year statute of limitations, ${ }^{62}$ Congress saw fit to impose a two-year limitation on all causes of action commenced after the effective date of the Act. ${ }^{63}$ Any action by an employee not brought within this two-year period from the time it accrued is barred. ${ }^{64}$ In most instances an employee, himself, cannot readily detect a violation of the Fair Labor Standards Act. Thus, the major part of the burden of enforcing the Act has fallen on the Wage and Hour Division. ${ }^{65}$ This enforcement is accomplished by periodic inspection of all establishments covered by the Act. In I946 only about 8 per cent were officially inspected and 50 per cent of these were found to violate some provision of the Act. ${ }^{66}$ This means that only a small percentage of all establishments are inspected every two years and that the statute of limitations imposed by the Portal Act will place an undue burden on the Wage and Hour Division and seriously restrict the opportunity of workers to bring employee suits. In the case of an inspection taking place more than two years after certain wages have accrued which discloses a violation of the Act, the employer can be enjoined from continuing the violation but the employees will already have become barred from bringing suit for compensation due them under the statute. This results from the fact that a cause of action based on the Fair Labor Standards Act has been held to "accrue" on the day wages become due and unpaid. ${ }^{67}$ Since the Portal Act further provides that

tions was held unconstitutional by the Supreme Court of Oregon when applied as a bar to a suit for overtime pay and liquidated damages under the Fair Labor Standards Act. Fullerton v. Lamn, $x_{77}$ Ore. $655, x_{3}$ P. 2 d 941 (1945); the decision was upheld by the Ninth Circuit Court of Appeals in Clarke Lumber Co. v. Kurth, $5^{2}$ F. 2 d 914 (C.C.A. gth, 1945); see also 45 Col. L. Rev. 444 (1945).

62 Administrator of the Wage and Hour and Public Contracts Division of the Department of Labor Annual Report to 8oth Cong. Ist Sess. (Jan. 2, 1947); see Hearings before a Subcommittee of the Committee on the Judiciary on S. 70, 8oth Cong. Ist Sess. (1947).

${ }_{63}$ Pub. L. No. 49, 8oth Cong. Ist Sess., \& 6 (May 14, r947).

${ }^{64}$ Actions to enforce causes of action accruing on or after May 14, 1947, must be brought within two years. Actions to enforce causes of action accruing before May 14, 1947, must be brought within two years, or the period prescribed by the applicable state statute of limitations, whichever is shorter. If the cause of action accrued prior to the date of the enactment of the Portal Act, the action shall not be barred if it is commenced within r 20 days after the date of the enactment of the Portal Act, i.e., by Sept. II, I947, unless, at the time of its commencement it is barred by an applicable state statute of limitations. Pub. L. No. 49, 8oth Cong. Ist Sess., $\$ 6$ (May ${ }_{4}$, I947).

${ }^{65}$ See Gerber and Galfand, Employees' Suits under the Fair Labor Standards Act, 95 U. of Pa. L. Rev. 505 (I947).

${ }^{66}$ Administrator of the Wage and Hour and Public Contracts Division of the Department of Labor, Annual Report to 8oth Cong. Ist Sess. (Jan. 2, I947).

${ }^{6} 7$ Reid v. Solar Corp., 6 WH Cases 508 (r947); Mid-Continent Petroleum Corp. v. Keen, r57 F. 2d 310, 3 r6 (C.C.A. 8th, I946); see Brooklyn Savings Bank v. O'Neil, 324 U.S. 697 (I945); Rigopoulos v. Kervan, I40 F. 2d 506 (C.C.A. 2d, 1943). 
a collective action will be deemed to be commenced as to an individual claimant, not on the date the original complaint was filed, but on the date when the employee filed his written consent to become a party, ${ }^{68}$ the time lag between accrual of the cause of action and commencement of the collective action is increased, bringing more actions under the statute of limitations. The President, upon approving the Act, recognized an immediate need for additional appropriations to augment the inspection and enforcement program of the Wage and Hour Division ". . . . in order to detect violations early enough to protect workers from undue losses." ${ }^{\prime 69}$ To date no additional appropriations have been forthcoming.

Thus, despite the emergency nature of the Portal Act, a considerable revision of the Fair Labor Standards Act seems to have taken place. Although the Portal Act does appear to create greater certainty for employers, and does relieve them from the allegedly tremendous burden ${ }^{70}$ of portal to portal claims, it accomplishes this at the expense of limiting, and in some cases abolishing, the rights of workers established nine years before by the "remedial and humanitarian" Fair Labor Standards Act. It is to be regretted that, in an area as vital to the national economy as this, such major changes have been made under the guise of an emergency without thorough examination and consideration, and without the public scrutiny the situation demanded.

\section{OVERLAPPING FEDERAL AND STATE REGULATION OF LABOR RELATIONS}

Even those members of the Senate Committee on Labor and Public Welfare who opposed the passage of most parts of the Labor-Management Relations Act gave complete approval to Section ro(a), believing that the clarification of relations between the federal Board and state boards through the amendment of Section ro(a) of the National Labor Relations Act was a wise solution to a complex problem. ${ }^{x} \mathrm{~A}$ comparison of the two sections may be made plain by setting forth Section Io (a) of the NLRA, ${ }^{2}$ with that part which is omitted from

${ }^{68}$ Pub. L. No. 49, 8oth Cong. rst Sess., § 7(b) (May I4, I947).

69 H.R. Doc. No. 247 , 8oth Cong. Ist Sess. (r947).

${ }^{70} \mathrm{~A}$ strong case has been made to the effect that the portal-to-portal claims were not actually so financially staggering to the employers. Sugar, The Truth about "Portal to Portal," 7 Law. Guild Rev. 23 (I947); Smethurst and Haslam, "Portal-to-Portal" and Other Retroactive Liabilities, I5 Geo. Wash. L. Rev. I3I (I947). But cf, Cotter, Portal to Portal Pay, 33 Va. L. Rev. 44 (I947).

× Report of the Senate Committee on Labor and Public Welfare on S. II26, Senate Report I05, Part 2, 8oth Cong. rst Sess., at 4I (I947).

2 National Labor Relations Act § Io(a), 49 Stat. 453 (I935), 29 U.S.C.A. § I6o(a) (1947): act hereinafter referred to as NLRA. 